\title{
Grain-size characteristics of deposits derived from different glacigenic environments of the Schirmacher Oasis, East Antarctica
}

\author{
Ashok K. Srivastava ${ }^{1 *}$, Pravin S. Ingle ${ }^{1}$, Harihar S. Lunge ${ }^{2}$, Neloy Khare ${ }^{3}$ \\ ${ }^{1}$ Department of Geology, SGB Amravati University, Amravati 444 602, India; e-mail: ashokamt2000@hotmail.com \\ ${ }^{2}$ Department of Statistics, SSC College, Amravati - 444 602, India \\ ${ }^{3}$ Ministry of Earth Sciences, Lodhi Road, New Delhi - 110003, India \\ * corresponding author
}

\begin{abstract}
Sediment samples have been collected from the Schirmacher Oasis and adjoining area in East Antarctica; these areas consist of polar ice, ice-free area, lakes and the coastal shelf area. The 37 samples have been analysed for their grain-size parameters and statistical relationships. The oasis is characterised by ongoing glacial processes, including deposition and erosion of the sediments by ice, meltwater and winds, thus influencing the sediments in various ways. Basic statistical grain-size parameters like graphic mean, standard deviation, skewness and kurtosis have been calculated for the four units. The sediments of all areas are almost all poorly to very poorly sorted, fine-skewed to near-symmetrical and platykurtic to leptokurtic in nature. Bivariate plots between the grain-size parameters have been interpreted. They do, apart from a few exceptions, not show any trend suggesting relationships between the sediments of the four landscape types. Both $\mathrm{t}$ - and F-tests have been applied on the samples, and the phi values and grain-size parameters have been analysed; these show that the group variances of the samples are not significant, but that the phi-values are significant.
\end{abstract}

Keywords: sedimentary petrology, granulometry, glacial sediments, Schirmacher Oasis, Antarctica

\section{Introduction}

The Schirmacher Oasis, East Antarctica, is a good site to study the erosional and depositional processes of a continental glacier. It is dominated by Precambrian metamorphics. Modern glacial sediments accumulate due to weathering of the basement, deposition of sediments by the ice sheet, meltwater currents, settling of sediments in lakes, wind activity, etc. The oasis has been studied for its general geology (Sengupta, 1986; Singh, 1986), heavy minerals (Lal, 1986; Srivastava et al., 2010), the geochemistry of the basement (Hoch \& To- bschall, 1988; Hoch, 1999; Hoch et al., 2001), structural and thermal characteristics of graphite (Parthasarathy et al., 2003), bedrock topography and subsurface structure (Sundararajan \& Rao, 2005), Holocene climate change (Sharma et al., 2007), climatological interpretation of clay minerals (Srivastava et al., 2011), and the geomorphological evolution of the oasis, including modeling of its lacustrine regime from $13 \mathrm{ka}$ ago to nowadays (Phartiyal et al., 2011).

Grain-size parameters of the glacial sediments of the area, as well as their statistical relationships have also been studied in the past, but were restricted to preliminary investiga- 
tions and based on a limited number of samples. Initially, Lal (1986) studied the grain-size parameters of twelve samples collected from the ice-free area of the oasis; he found that the grain size of the sediments varies from coarse sand to clay and that the sediments have a moderate sorting. Asthana \& Chaturvedi (1998) also studied some grain-size parameters and interrelationships of eighteen samples from the southern margin of the Schirmacher Oasis. They found that the coarse to fine grain size of the sediments with bad sorting and their polymodal distribution are due to changes in the velocity of the transporting medium, i.e. the wind. Recently, Srivastava et al. (2009) differentiated the sediments of various glacial units on the basis of their grain-size characteristics. They also studied the roles of the depositional agents and the geomorphology and concluded that it is difficult to differentiate the sediments of the various areas on the basis of their grainsize parameters, but this conclusion was based on the analysis of nineteen samples only.

The above implies that little is known as yet about the sediments of the Schirmacher Oasis. The objective of the present study was therefore (1) to obtain insight into the grain-size parameters of the glacial sediments and their statistical relationships, (2) to identify possible relationships between the grain-size parameters of sediments from the four types of areas under study, viz. polar ice, the ice-free area (in the sense of neither being covered by glacial ice, nor being a lake), lakes and the coastal shelf region, and (3) to establish the group variances between the sediments from these four are types. This study is based on thirty-seven samples, including the nineteen samples that had been analysed earlier (Srivastava \& Khare, 2009). The new results should provide more details and more accurate data than the earlier findings, also because statistical analyses have now been applied.

\section{Geological and glacial units}

The Schirmacher Oasis (70 $44^{\prime} 30^{\prime \prime}-70^{\circ} 46^{\prime} 30^{\prime \prime}$ $S$ and $11^{\circ} 22^{\prime} 40^{\prime \prime}-11^{\circ} 54^{\prime} 00^{\prime \prime} \mathrm{E}$ ) is an ice-free, E-W trending narrow strip of land, covering an area of about $35 \mathrm{~km}^{2}$ with a maximum width of 2.7 $\mathrm{km}$ in its central part. The exposed rocks form a high-grade metamorphic suite and represent the Precambrian crystalline basement. The major rock types are banded gneiss, alaskite, garnet-biotite gneiss, calc-gneiss, khondalites and associated migmatites, augen gneiss and streaky gneiss, which are at places intruded by dykes of basalt, lamprophyre, pegmatite, dolerite and apatite (Sengupta, 1986) (Fig. 1).

The study area can be roughly divided into four types of area, viz. (1) the polar ice sheet (PIS), (2) the ice-free area (IFA) of the Schirmacher Oasis, (3) lakes (LKS) on the ice-free area, and (3) the coastal shelf (CSH) area (Fig. $1)$; hereafter, these area types will be referred to by their abbreviations. All four types extend roughly in an E-W direction, as does the coastline.

The PIS covers a large area in the south. Its northern boundary is formed by a scarp-face showing horizontal layers of ice. These layers differ in thickness, transparency, shades of brown colour (Fig. 2A) and degree of melting. The ice sheet contains abundant silts and sands, which are more pronounced in and along meltwater channels and depressions formed on the top surfaces, and on the scarp face. Another site for sampling sediments is along the base of the scarp face, where the meltwater with the sedimentary particles derived from the ice sheet drips down and forms small accumulations of sediment.

The IFA has a northern peripheral E-W trending strip that is inclined towards the coastal shelf, whereas the southern boundary is formed by the polar ice sheet. This type of area shows an undulating topography because of low-altitude (50-200 m) hills, glacial lakes and plains, Ushaped valleys and depressions (Fig. 2B). Winds from the south-east with velocities up to almost $50 \mathrm{~m} \mathrm{~s}^{-1}$ are common here (Chaturvedi et al., 1999; Bera, 2004; Lal \& Manchurkar, 2007); they erode sediments that have been set free through weathering and erosion of ice-free area, and they deposit these sediments in depressions, windshadow zones, valleys, etc. Glacigenic processes such as meltwater flowing through channels are additional factors that affect erosion and accumulation of sediments. 
Numerous lakes (LKS) of various origin are present on the ice-free area. In these lakes, sediment accumulation takes place due to gravitational transport from the surrounding higher area, as well as from the entire catchment area that drains into the lakes (Fig. 2C). Locally, the relatively fine-grained sediments in the lakes are mixed with pebble-sized angular to subangular clasts derived from the basement and intrusives. These pebble admixtures are still

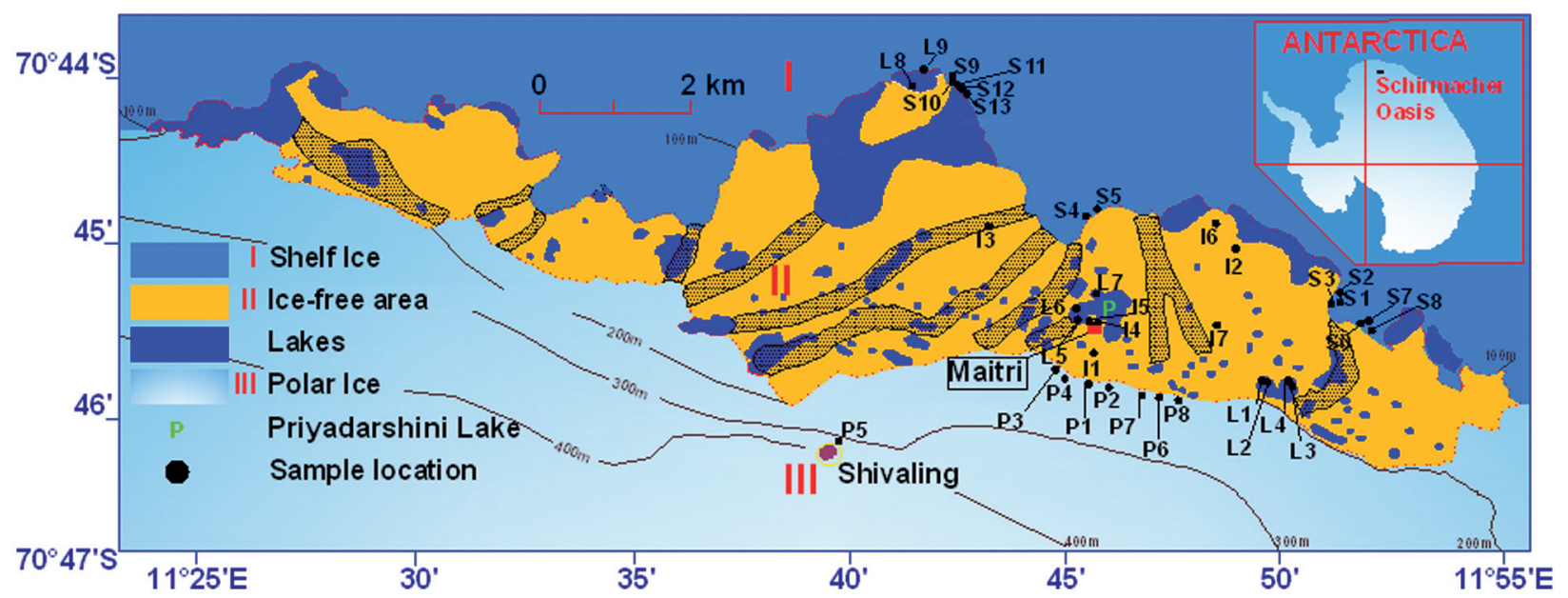

Fig. 1. Map of the Schirmacher Oasis showing significant glacial units, elevations, paths of fossil glaciers (after Ravindra, 2001; Gajananda et al., 2007) and locations of sampling sites; P1-P8: polar ice sediments, L1-L9: lake sediments, I1-I7: ice-free area sediments, and S1-S13: coastal shelf sediments.
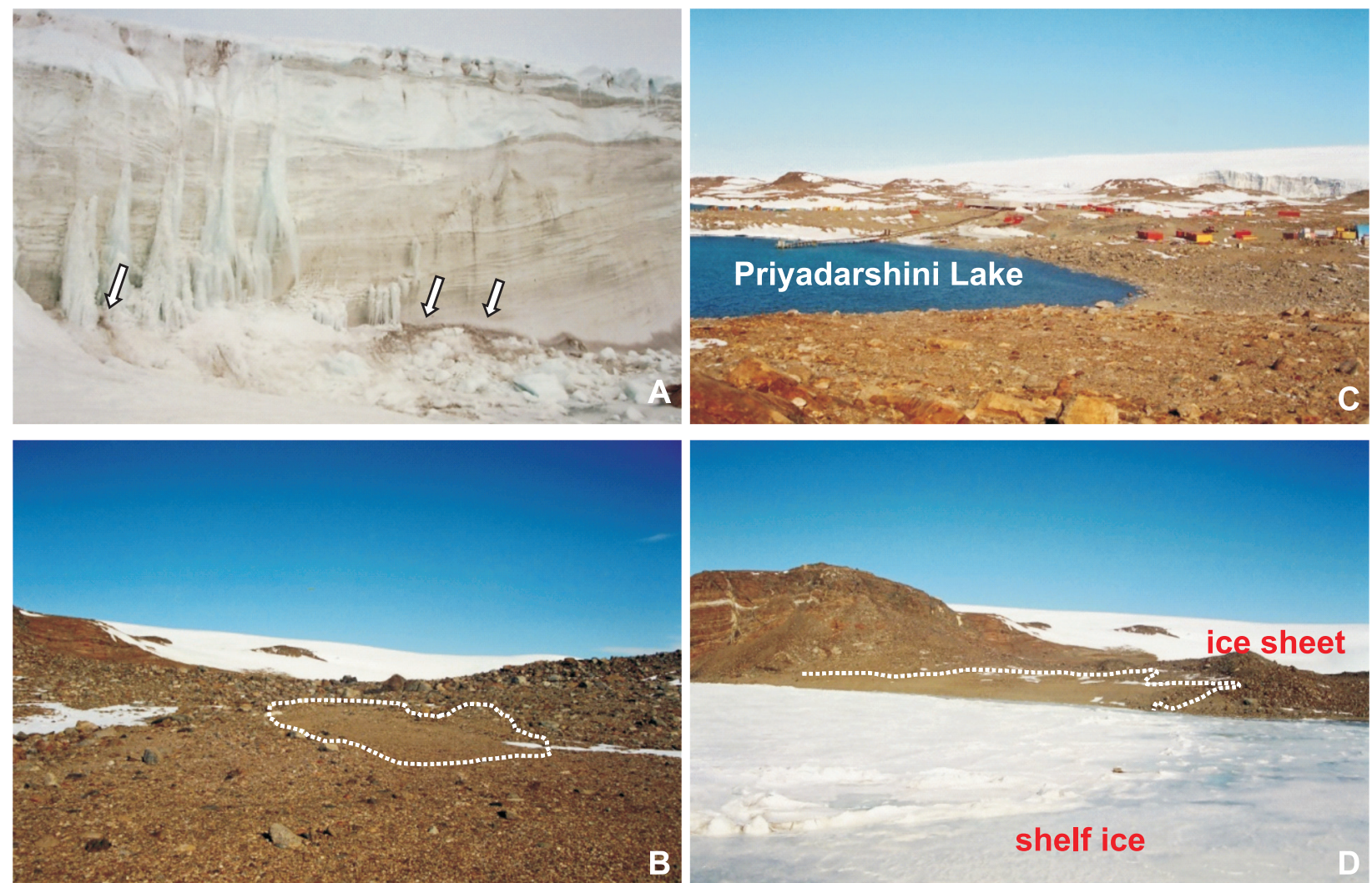

Fig. 2. The areas from which samples have been collected.

A: Scarp face of the ice sheet south of Maitri. The arrows indicate sites with sediment accumulations. B: Ice-free area with a patch of loose sediments. C: Ice-free area and Priyadarshini Lake. D: Shelf north of Maitri. The marked area is a patch of loose sediments. 
present at a depth of 1-2 $\mathrm{m}$, as observed during sampling in pits and channels (Phartiyal et al., 2011).

The E-W trending $\mathrm{CSH}$ is also overlain by a thick cover of ice, but the marginal area is exposed in the form of narrow strip coinciding with the northward sloping southern boundary of the ice-free area.The coast is not exposed continuously but some patches of poorly consolidated sediments, occasionally showing horizontal stratification, are present (Fig. 2D). The area is fed with sediments by meltwater streams which form by melting of both the polar ice sheet and other small glaciers, and which take a route towards the north through the ice-free area and finally reach the coastal shelf area. The sediments are commonly medium to coarse sands. Sorting and concentration of clasts show lateral variations.

\section{Samples and sample sites}

Thirty-seven samples have been collected. Eighteen of them are new; nineteen have been described earlier (Srivastava \& Khare, 2009). The samples consist of loose admixtures of sand, silt and clay in variable proportions. Eight samples come from the PIS, 7 from the IFA, 9 from the LKS and 13 from the CSH. They were randomly collected from all over the Schirmacher Oasis area, including various glacial units. In the case of the PIS, the samples were collected either directly from the ice or from small debris accumulations on the surface along the scarp face; the samples from the other areas were taken from a depth of 15-20 $\mathrm{cm}$. The new samples are indicated in the following with symbol *, whereas the earlier collected samples are indicated with symbol \#.

\subsection{Polar ice sheet}

The eight samples from this area type were either embedded in the ice, or formed part of accumulations in surface depressions, or were taken from the scarp face or from the sedimentary surface just in front of the sheet from which they had transported by meltwater streams that had formed due to melting of the ice.The precise locations where the samples from the PIS were taken are:

\#P-1: the base of the PIS scarp face, south of Maitri;

\#P-2: the scarp face about 400 m east of P1, 3

$\mathrm{m}$ above the sedimentary surface;

*P-3: the top of the 2-m thick ice near the scarp face, SW of Maitri;

\#P-4: along the base of the ice sheet, SW of Maitri;

\#P-5: a frozen meltwater channel at of the top of the ice sheet near Shivaling, about $3 \mathrm{~km}$ SW of Maitri;

\#P-6, *P-7 and *P-8: the ice sheet near the scarp margin south of Maitri, where they were collected at sites with mutual distances of approx. $500 \mathrm{~m}$.

\subsection{Ice-free area}

The sixteen samples were collected from the ice-free area, where wind is a significant factor determining erosion, transport and accumulation of particles, in addition to the glacigenic activity in the form of meltwater streams.

The precise sample locations on the ice-free area are:

\#I-1: 400 m south of Maitri;

\#I-2 and I-6: about $2 \mathrm{~km}$ NE of Maitri;

*I-3: about $2 \mathrm{~km}$ NW of Maitri;

\#I-4 and *I-5: a sand pocket near the Maitri

station;

*I-7: about $1.5 \mathrm{~km}$ east of Maitri.

\subsection{Lakes}

The samples were collected from lakes on the ice-free area to which meltwater streams supplied sediments, but where sediment was also derived from downslope sediment transport from uplands and adjoining areas.

The precise sample locations of the lake sediments are:

\#L-1 and *L-2: a lake margin about $2 \mathrm{~km}$ east of Maitri;

${ }^{*} \mathrm{~L}-3$ and ${ }^{*} \mathrm{~L}-4$ : the margin of another lake adjacent to the just-mentioned lake; 
${ }^{*} \mathrm{~L}-5, \# \mathrm{~L}-6$ and ${ }^{*} \mathrm{~L}-7$ : the margin of Priyadarshini Lake near Maitri;

\#L-8 and *L-9: the margin of a lake in the extreme north, about $5 \mathrm{~km}$ from Maitri.

\subsection{Coastal shelf}

This area is a northward dipping part of the Schirmacher oasis which downwards gradually passes into the coastal area. The sediments are mixed with glaciofluvial sediments from the ice-free area, north of the oasis. Strong winds affect the exposed areas of the loosely packed sediments.

The precise sample locations are:

\#S-1, *S-2 and *S-3: the shelf at 3-4 km east of Maitri;

*S-4 and *S-5: approx. $2 \mathrm{~km}$ north of Maitri;

*S-6, \#S-7 and \#S-8: approx. 4 km east of Maitri;

*S-9, \#S-10, *S-11, \#S-12 and *S-13: different sites, situated close to each other, about 5 km NW of Maitri.

\section{Methods}

Hundred grams of each sediment sample were treated with diluted $\mathrm{HCl}$ and hydrogen peroxide in order to remove carbonates and organic matter. Then the grain-size analysis was carried out by sieving following Ingram (1971). The sieves had meshes of $-1.25 \Phi,-0.75$ $\Phi,-0.25 \Phi, 0.35 \Phi, 0.75 \Phi, 1.50 \Phi, 2.00 \Phi, 2.60 \Phi$, $3.0 \Phi, 3.50 \Phi, 4.10 \Phi$, and $4.25 \Phi$. The samples were shaken by a motorised sieve shaker for thirty minutes (Lindholmn, 1987). The weight of the thus obtained fractions were calculated as weight percentages, which were further computed for graphical representations in the form of weight-percentage curves and cumulative curves and histograms. The graphic measures have been computed on the basis of data obtained from the cumulative curves, as proposed by Folk \& Ward (1957) and Folk (1980) (Table 1).

\section{Results}

\subsection{Weight percentages and cumulative curves}

Both weight-percentage frequency curves and cumulative weight-percentage frequency curves have been prepared in order to identify possible trends (Fig. 3A-D). Comparison of these curves for the sediments of all four area types indicates that the PIS, LKS and CSH sediments are polymodal in nature, whereas the IFA sediments have do not show any trend. In the case of the first three area types, three grainsize fractions can be clearly distinguished: medium sand dominates, but coarse and fine sand are also well represented. The polymodal nature of these sediments indicates the influence of various transporting agents, viz. wind, meltwater and gravitation. The absence of any trend in the IFA sediments is due to mixing of particles supplied by the various tranporting agents.

The cumulative curves of all samples have been plotted on a probability scale, which makes the poor grain sorting well visible (Fig. 4). Visher (1969) interpreted various modes of sediment transport, viz. by traction, saltation and suspension by distinguishing three distinct sectors of the curve in the form of straight lines of different lengths and slopes. Most of the curves for the sediments under study here, however, lack such different sectors because it is difficult to find any dominant straight line in the curves. This must be ascribed to the influence of the variety of physical processes involved simultaneously in the deposition of the sediments. It can nevertheless be deduced from the curves that traction was the most prominent form of transport, followed by saltation, while suspension was of minor importance. Mycielska-Dowgiałło \& Ludwikowska-Kędzia (2011) tried to classify cumulative curves on the basis of the degree of sorting and inclination of curve segments, thus distinguishing (1) curves of well sorted sediments constituting $>60 \%$ of the total sample mass, (2) poorly 
Table 1. Graphic measures and textural parameters of the samples belonging to the various types of areas from which samples were collected.

\begin{tabular}{|c|c|c|c|c|c|c|c|c|c|c|c|c|c|c|}
\hline \multirow{2}{*}{$\begin{array}{c}\text { tex- } \\
\text { tural } \\
\text { fea- } \\
\text { tures/ } \\
\text { sam- } \\
\text { ple } \\
\text { num- } \\
\text { bers }\end{array}$} & \multicolumn{8}{|c|}{ N-values } & \multirow[b]{2}{*}{$\begin{array}{c}\mathrm{C} \text { [in } \\
\text { mi- } \\
\text { cron] }\end{array}$} & \multirow[b]{2}{*}{$\begin{array}{c}\text { M [in } \\
\text { mi- } \\
\text { cron] }\end{array}$} & \multicolumn{4}{|c|}{ grain-size parameters } \\
\hline & $\Phi 95$ & $\Phi 84$ & $\Phi 75$ & $\Phi 50$ & $\Phi 25$ & $\Phi 16$ & $\Phi 5$ & $\Phi 1$ & & & MZ & o1 & Sk1 & KG \\
\hline P-1 & 4.41 & 2.98 & 2.74 & 1.69 & 0.36 & -0.94 & -1.53 & -2.77 & 6821 & 310 & 1.24 & 1.88 & +0.21 & 1.10 \\
\hline P-2 & 4.45 & 2.76 & 2.26 & 1.51 & 0.45 & -0.77 & -1.40 & -2.50 & 5656 & 350 & 1.17 & 1.78 & -0.14 & 1.32 \\
\hline P-3 & 4.42 & 3.41 & 3.13 & 2.66 & 1.57 & 0.74 & -1.04 & -1.90 & 3732 & 160 & 2.27 & 1.48 & +0.38 & 1.43 \\
\hline P-4 & 4.37 & 3.15 & 2.81 & 1.62 & 0.38 & -0.89 & -1.44 & -2.39 & 5241 & 320 & 1.29 & 1.81 & +0.14 & 0.98 \\
\hline P-5 & 4.32 & 2.95 & 2.81 & 1.97 & 1.52 & 1.06 & 0.47 & -0.72 & 647 & 260 & 1.99 & 1.00 & +0.12 & 1.22 \\
\hline P-6 & 3.31 & 2.69 & 1.95 & 0.67 & -0.73 & -1.03 & -1.37 & -2.06 & 4169 & 640 & 0.77 & 1.63 & +0.11 & 0.71 \\
\hline P-7 & 3.41 & 2.95 & 2.76 & 1.60 & -1.14 & -1.77 & -2.55 & -4.76 & 27095 & 330 & 0.98 & 2.08 & +0.40 & 0.62 \\
\hline P-8 & 4.24 & 2.96 & 2.61 & 1.12 & -0.85 & -1.29 & -1.78 & -3.06 & 8339 & 460 & 0.93 & 1.98 & -0.05 & 0.71 \\
\hline L-1 & 4.25 & 2.94 & 2.71 & 1.49 & -0.23 & -0.89 & -1.43 & -2.18 & 4531 & 360 & 1.18 & 1.81 & +0.13 & 0.73 \\
\hline L-2 & 3.89 & 3.08 & 2.80 & 1.61 & -0.31 & -1.09 & -1.75 & -3.07 & 8397 & 325 & 1.20 & 1.89 & +0.24 & 0.74 \\
\hline L-3 & 4.71 & 4.05 & 3.15 & 1.67 & 0.0 & -0.49 & -1.17 & -1.57 & 2969 & 320 & 1.64 & 2.13 & -0.006 & 0.76 \\
\hline L-4 & 3.41 & 2.44 & 1.61 & 0.41 & -1.14 & -1.43 & -1.82 & -2.86 & 7260 & 750 & 0.47 & 1.75 & +0.09 & 0.77 \\
\hline L-5 & 4.45 & 2.83 & 2.21 & 1.25 & 0.36 & -0.64 & -1.38 & -2.03 & 4084 & 420 & 1.14 & 1.74 & +0.01 & 1.29 \\
\hline L-6 & 4.20 & 3.29 & 2.93 & 1.73 & -0.66 & -1.31 & -2.07 & -3.90 & 14928 & 295 & 1.23 & 2.19 & +0.26 & 0.71 \\
\hline L-7 & 4.02 & 3.15 & 2.84 & 1.72 & -0.87 & -1.53 & -2.40 & -4.66 & 25281 & 300 & 1.11 & 2.04 & +0.33 & 0.70 \\
\hline L-8 & 3.41 & 2.85 & 2.59 & 1.58 & 0.48 & -0.58 & -1.45 & -2.66 & 6320 & 340 & 1.28 & 1.50 & +0.25 & 0.94 \\
\hline L-9 & 3.94 & 3.15 & 2.84 & 1.51 & -1.17 & -1.81 & -2.57 & -4.83 & 28442 & 350 & 0.95 & 2.22 & +0.28 & 0.66 \\
\hline I-1 & 4.39 & 3.38 & 3.10 & 2.46 & 2.02 & 1.06 & 0.49 & -0.87 & 1827 & 185 & 2.3 & 1.17 & +0.10 & 1.48 \\
\hline $\mathrm{I}-2$ & 3.74 & 2.81 & 2.20 & 1.03 & -0.49 & -1.17 & -1.72 & -3.39 & 10483 & 480 & 0.89 & 2.25 & +0.10 & 0.83 \\
\hline I-3 & 4.12 & 3.22 & 2.93 & 2.37 & 1.62 & 1.23 & -0.79 & -2.08 & 4228 & 192 & 2.27 & 1.23 & +0.21 & 1.53 \\
\hline $\mathrm{I}-4$ & 4.23 & 3.20 & 2.93 & 2.22 & 1.51 & 0.70 & -1.68 & -3.52 & 11471 & 215 & 2.07 & 1.52 & +0.25 & 1.70 \\
\hline $\mathrm{I}-5$ & 2.93 & 2.39 & 1.91 & 1.50 & 1.05 & 0.90 & -0.58 & -2.51 & 5696 & 355 & 1.59 & 0.89 & -0.01 & 1.12 \\
\hline I-6 & 4.28 & 3.44 & 3.16 & 2.64 & 0.75 & 0.47 & -1.38 & -2.41 & 5314 & 160 & 2.18 & 1.59 & +0.37 & 0.96 \\
\hline $\mathrm{I}-7$ & 3.45 & 2.86 & 2.55 & 1.22 & -0.58 & -1.25 & -1.96 & -3.71 & 13086 & 430 & 0.94 & 1.83 & +0.19 & 0.70 \\
\hline S-1 & 4.22 & 2.92 & 2.70 & 1.73 & 0.66 & 0.19 & -1.42 & -2.58 & 5979 & 295 & 1.61 & 1.53 & +0.07 & 1.13 \\
\hline S-2 & 4.60 & 3.39 & 2.95 & 1.95 & 0.56 & 0.31 & -1.49 & -3.66 & 12640 & 260 & 1.88 & 1.69 & +0.15 & 1.03 \\
\hline S-3 & 3.09 & 2.77 & 2.56 & 1.85 & 1.51 & 1.09 & 0.47 & -0.96 & 1945 & 280 & 1.90 & 0.81 & +0.04 & 1.03 \\
\hline S-4 & 4.56 & 3.39 & 2.86 & 1.62 & -0.26 & -1.06 & -1.78 & -3.10 & 8574 & 325 & 1.31 & 2.08 & -0.06 & 0.83 \\
\hline S-5 & 4.30 & 3.26 & 2.14 & 2.19 & 1.22 & 0.48 & -1.36 & -2.36 & 5133 & 220 & 1.97 & 1.55 & +0.23 & 1.35 \\
\hline S-6 & 4.35 & 3.42 & 2.98 & 2.09 & 0.69 & -0.16 & -1.31 & -2.38 & 5205 & 235 & 1.78 & 1.75 & +0.22 & 1.05 \\
\hline S-7 & 3.76 & 2.87 & 2.69 & 1.72 & -0.32 & -1.26 & -2.14 & -4.37 & 20677 & 300 & 1.11 & 1.91 & +0.37 & 2.02 \\
\hline S-8 & 3.71 & 3.05 & 2.90 & 2.62 & 1.82 & 1.61 & 0.54 & -1.82 & 3530 & 165 & 2.42 & 0.84 & -0.15 & 1.20 \\
\hline S-9 & 4.15 & 3.05 & 2.83 & 1.92 & 0.07 & -1.05 & -1.79 & -3.17 & 9000 & 265 & 1.27 & 1.92 & +0.30 & 0.88 \\
\hline S-10 & 3.35 & 2.86 & 2.68 & 1.02 & -0.47 & -0.97 & -1.97 & -4.47 & 22161 & 490 & 0.97 & 1.75 & +0.08 & 0.69 \\
\hline S-11 & 4.05 & 2.85 & 2.42 & 0.93 & -0.33 & -1.05 & -1.77 & -3.03 & 8168 & 520 & 0.91 & 1.66 & +0.03 & 0.86 \\
\hline S-12 & 3.14 & 2.66 & 2.00 & 1.33 & 0.26 & -0.91 & -1.37 & -2.12 & 4346 & 395 & 1.02 & 1.57 & +0.22 & 1.05 \\
\hline S-13 & 4.18 & 3.44 & 3.19 & 2.59 & 0.51 & -0.83 & -1.52 & -3.01 & 8055 & 168 & 1.73 & 1.92 & +0.52 & 0.87 \\
\hline
\end{tabular}

sorted sediments constituting $>60 \%$ of the total sample mass, and (3) a transitional group comprising mixed sediments formed by relatively short-lived depositional processes. Our curves most closely resemble the second group of $\mathrm{cu}$ mulative curves, comprising fractions from silt to coarse gravel, a characteristic of sediments transported by a medium of consider- 

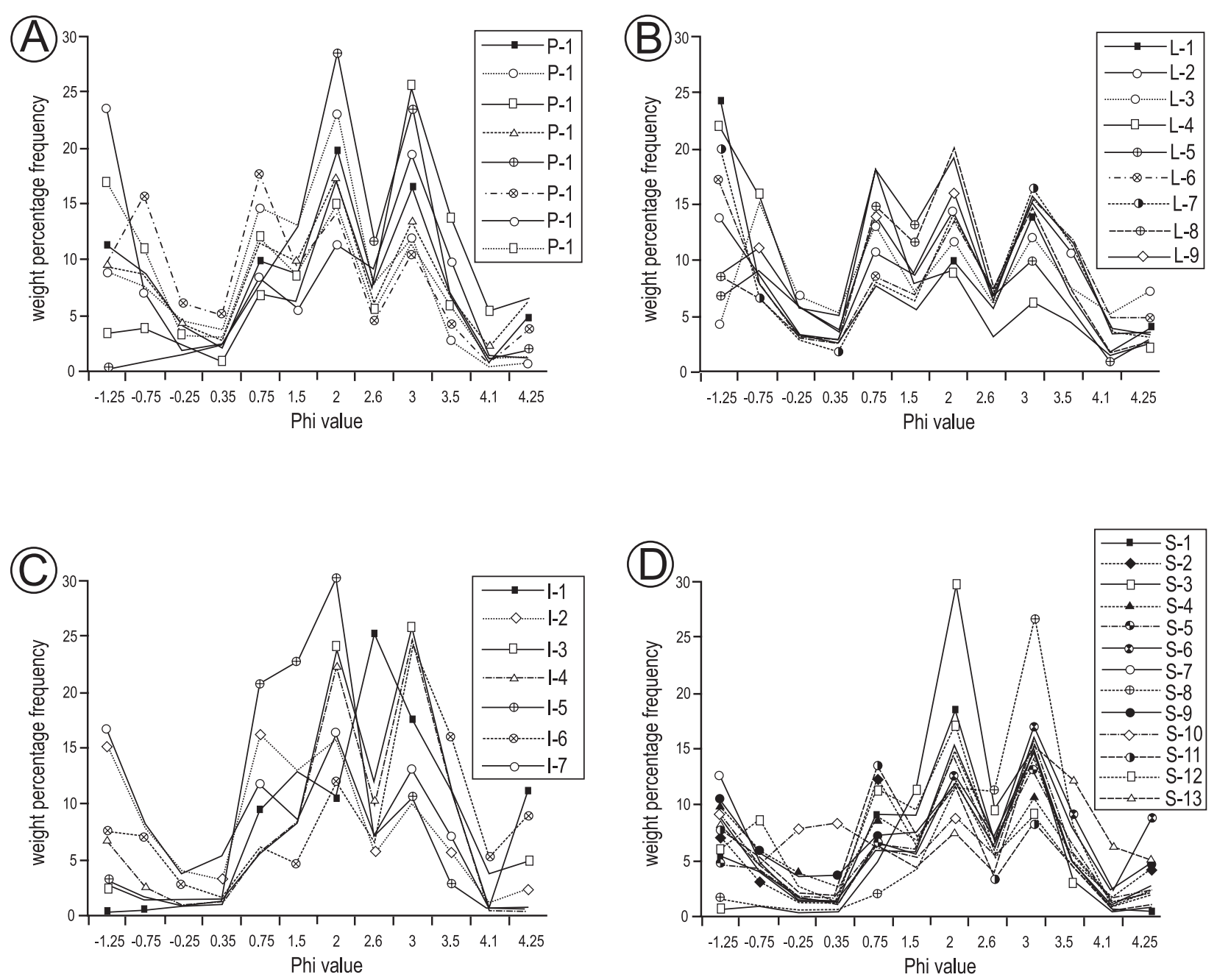

Fig. 3. Weight-percentage curves of the samples.

A: Polar ice sheet. B: Lakes. C: Ice-free area. D: Coastal shelf area.

able density: tills (cf. Mycielska-Dowgiałło \& Ludwikowska-Kędzia, 2011).

\subsection{Grain-size parameters}

Table 1 shows the calculated values of various grain-size parameters, viz. the mean, the median, the skewness, the kurtosis and the standard deviation of the PIS, IFA, LKS and $\mathrm{CSH}$ sediments. The calculation of the various parameters follows Folk \& Ward (1957).

\subsubsection{Mean grain size $\left(M_{z}\right)$}

The mean grain size is a parameter related to the overall grain size. The range and average values for the PIS, LKS, IFA and CSH sediment are 0.93-2.27 $\Phi$ (average 1.33 $\Phi$ ), 0.47-1.64 $\Phi$ (average 1.33 $\Phi$ ), 0.89-2.30 $\Phi$ (average 1.74 $\Phi$ ) and 0.91-2.42 $\Phi$ (average 1.52 $\Phi$ ), respectively.

The average mean grain-size values of all four areas indicate the predominance of medium sand, but each area may show local variations, ranging from coarse to fine sand.

\subsubsection{Standard grain-size deviation $\left(\sigma_{1}\right)$}

The standard deviation measures the sorting or the uniformity of the grain-size distribution. The values obtained from the PIS ranges from $1.00 \Phi$ to $2.08 \Phi$ (average $1.70 \Phi$ ), indicating poor sorting. The same is shown by the LKS sediments, which range from $0.47 \Phi$ to $1.64 \Phi$ (average $1.91 \Phi)$, whereas the IFA and $\mathrm{CSH}$ sediments have averages of $1.49 \Phi$ and $1.61 \Phi$, in the range of 0.89 to $2.25 \Phi \& 0.81$ to $2.08 \Phi$, respectively. 

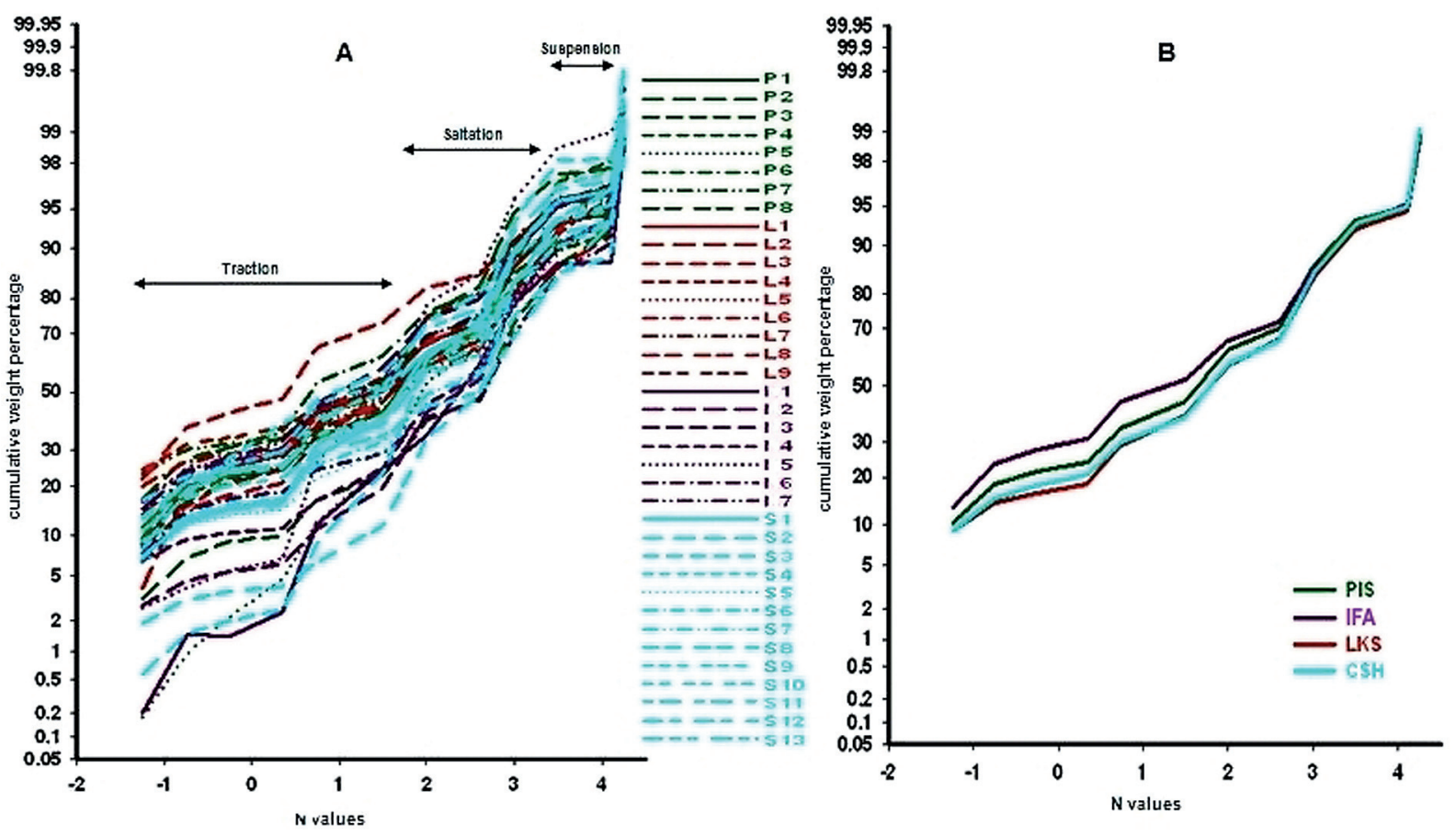

Fig. 4. Cumulative curves of all samples, indicating poor grain sorting and traction as the prominent mode of sediment transport.

A: Based on the data of all samples. B: Based on averaged data of four area types.

The average values of all the areas thus belong to the category of poor sorting (1.00-2.00 $\Phi)$, with $\mathrm{LKS}<\mathrm{PIS}<\mathrm{CSH}<\mathrm{IFA}$ regarding the sorting.

\subsubsection{Skewness ( $\left.\mathrm{Sk}_{1}\right)$}

Skewness is a measure of symmetrical distribution, i.e. the proportion of coarse or fine fractions. A symmetrical curve with excess fine material shows a positive value, whereas one with excess coarse material shows a negative value; a zero value is indicated by a symmetrical curve.

The skewness values derived from the four area types show a dominance of fine skewed sediments followed by near-symmetrical ones, except for the PIS, which is characterised by a very fine-skewed sediment curve. Almost the same characteristic (i.e., fine skewed to nearsymmetrical) is also exhibited by the area as a whole, which indicates a relatively high proportion of fine material.

\subsubsection{Kurtosis $\left(\mathrm{K}_{\mathrm{G}}\right)$}

The kurtosis expresses the peakedness of the grain-size distribution. The average value of the PIS sediments indicates a mesokurtic condition (average $1.01 \Phi$ ), whereas the LKS indicates a platykurtic condition (average 0.81 $\Phi)$. The IFA (average $1.18 \Phi$ ) and CSH (average $1.70 \Phi$ ) sediments are leptokurtic. The area as a whole shows a dominance of platykurtic sediments (15 samples) followed by leptokurtic (9 samples) and mesokurtic (8 samples) sediments. Very leptokurtic (3 samples) and very platykurtic (2 samples) sediments are much less frequent.

\subsection{Bivariate plots}

Bivariate plots are widely used to differentiate between fluvial, dune and beach environments (Friedman, 1961, 1967; Miola \& Weiser, 1968). Their application is rather uncommon in glacial sediments, however. The present samples from the various glacigenic areas are therefore investigated in this way to test whether glacigenic sediments can thus reveal any possible relationship, too.

Plotting the mean vs. the standard deviation of the PIS and LKS sediments shows clustering 
of sediment near the boundary of coarse and medium, poorly to very poorly sorted sand $(\sim 1$ $\Phi)$ (Fig. 5A). The IFA sediments lack any clear pattern, but there is a tendency of clustering, showing poor sorting of the coarse-grained sediments. The CSH sediments are dominantly medium-sized, poorly sorted sands. The sediments of all areas are, as a rule, poorly to very poorly sorted.

The scattering shown in the plot of the mean grain size vs. the skewness of the PIS and LKS sediments shows a tendency of relatively more fine material in medium-grained sands
(Fig. 5B). The skewness of the IFA sediments shows more fine sand, whereas the average medium-size CSH sediments are dominantly near-symmetrical to skewed towards finer particles. The overall assemblage of the points of all the samples shows two clusters, which both indicate near-symmetrical to very finely skewed sediments. However, one clustering comprises points near the boundary of coarse and medium sand, whereas the second cluster comprises points that cover a large range, from medium to fine sand.

\section{(A)}

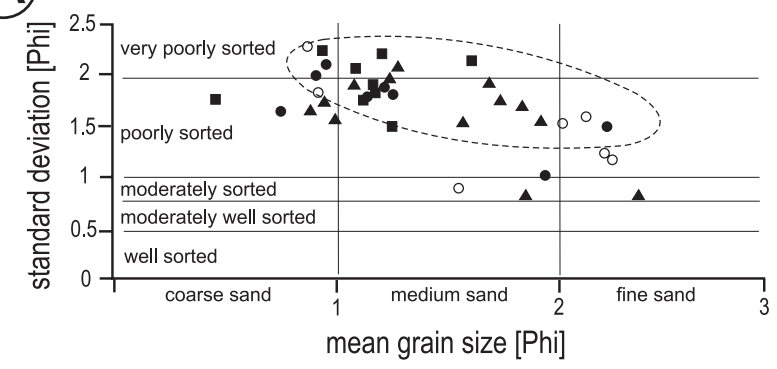

(C)

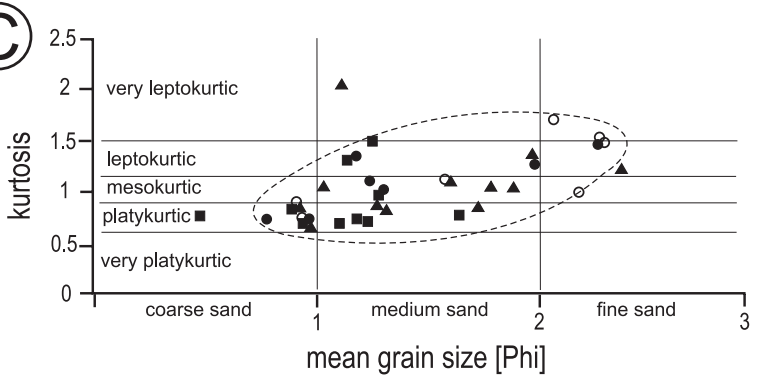

(E)

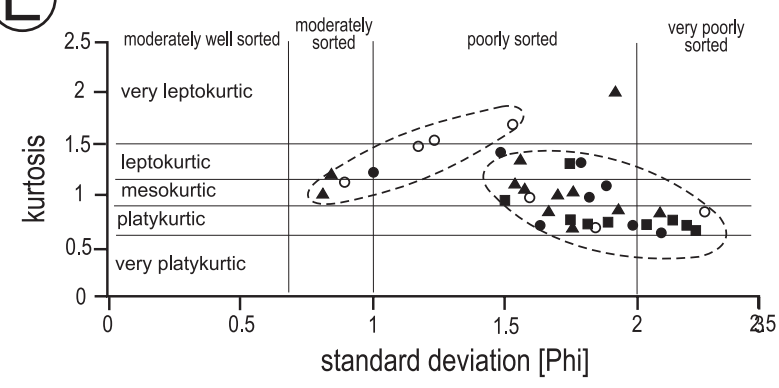

(B)
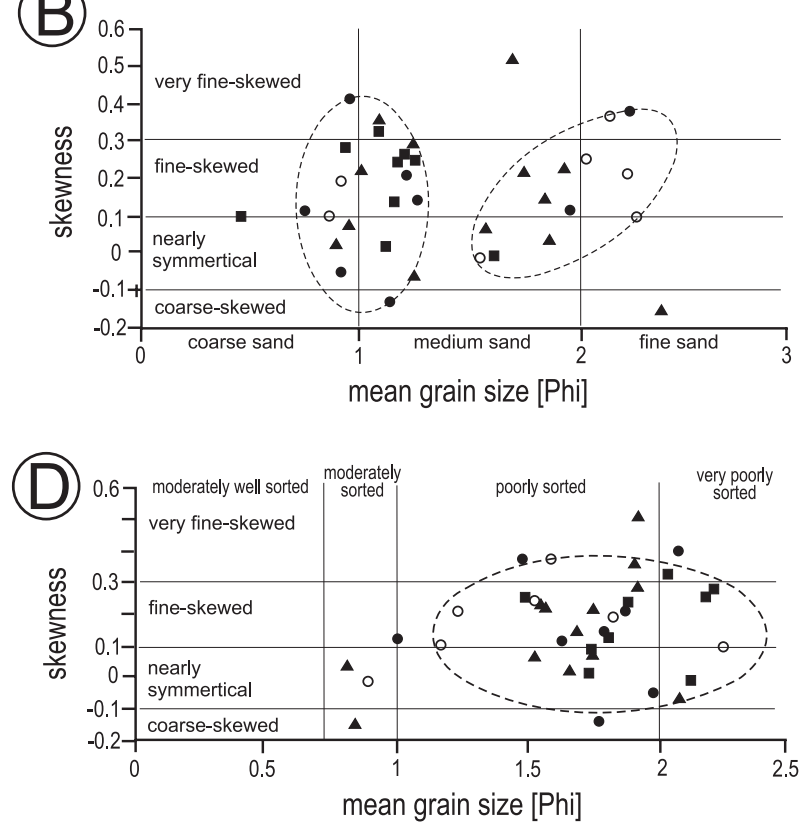

(F)

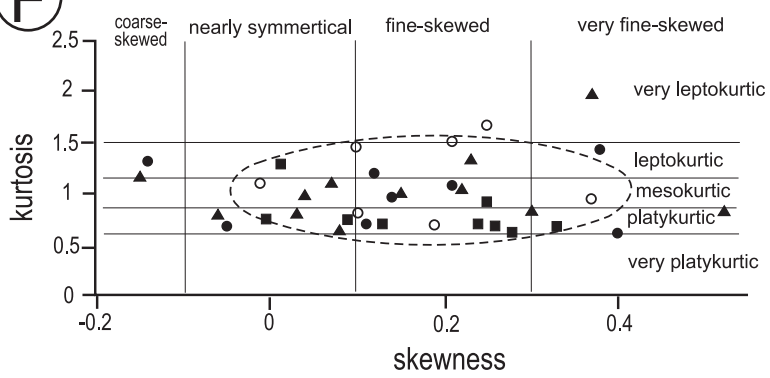

- PIS $\quad$ LKS OIFA $\triangle \mathrm{CSH}$

Fig. 5. Bivariate plots.

A: Mean vs. standard deviation, showing poor grain sorting. B: Mean vs. skewness, showing clustering of points in two groups. C: Mean vs. kurtosis, showing the platykurtic to mesokurtic nature of the sediments. D: Standard deviation vs. skewness, showing the poorly sorted nature of the sediments. E: Standard deviation vs. kurtosis, showing two different trends. F: Skewness vs. kurtosis, showing concentrations of grains in the platykurtic to mesokurtic categories. The ellipses represent the areas of concentration of points. 
The plot of the mean grain size vs. kurtosis indicates a very weak relationship for the separate areas (Fig. 5C), although the $\mathrm{CSH}$ sediments, most of which have a medium grain size, are exceptionally peaked and flat-peaked. In general, the sediments consisting of medium sand are platykurtic to mesokurtic; they show a tendency to become more leptokurtic with decreasing mean grain size.

The plot of the standard deviation vs. skewness of the PIS and IFA sediments lack any clear pattern (Fig. 5D). The LKS sediments show a tendency of the skewness to increase towards fine with decreasing sorting, which tendency is also vaguely present in the poorly sorted $\mathrm{CSH}$ sediments. The area as a whole is dominated by poorly sorted sediments, followed by very poorly sorted sediments. There is a tendency of a gradual decrease in sorting with increasing proportions of fine-grained sediments.

The standard deviation vs. kurtosis for the PIS shows a decrease of the kurtosis with decreasing sorting, whereas the LKS sediments are mostly platykurtic near the boundary between poorly and very poorly sorted sediment (Fig. 5E). The IFA sediments show no relationship, whereas the CSH sediments have a vague tendency of proportional decrease in kurtosis with increasing sorting. The analysis of the entire area shows two trends, viz. (1) a vague tendency of increasing kurtosis with decreasing sorting in a few sediments of the IFA and PIS, and (2) a decrease in kurtosis with decreasing sorting in the range of 1.5-2.5 $\Phi$ values.

The skewness vs. kurtosis plot lacks any pattern, as there is a wide scatter of points of the various glacigenic areas (Fig. 5F). The overall picture reveals that the near-symmetrical to fine-skewed sediments show a maximum scattering in the platykurtic category, followed by the mesokurtic and leptokurtic categories.

$\mathrm{C}-\mathrm{M}$ patterns can be applied to establish a possible relationship between the depositional environment and the hydrodynamic forces involved in the deposition of sediments (Passega, 1957, 1964; Passega \& Byramjee, 1969). The two parameters, ' $C$ ' (which denotes the one-percentile value, representing the maximum grain size in microns) and ' $\mathrm{M}$ ' (the medium grain size in microns), are plotted on logarithmic paper. The pattern is related to the nature of the various types of sediment and the energy of the transporting medium. The diagram shows various segments: $\mathrm{ON}$ (rolling), $\mathrm{PO}$ (rolling and suspension), QP (suspension and rolling), RQ (graded suspension), SR (uniform suspension) and $\mathrm{T}$ (pelagic suspension). The plot distinguishes fields of rolled sediments (I, II, III and IX) and suspension of minor importance (IV, V, VI, VII and VIII). Accordingly, the points of the samples under study fall within fields I and II in the upper right part of the plot, which denotes rolled sediments with a $C$ value of more than one. It is therefore difficult to find

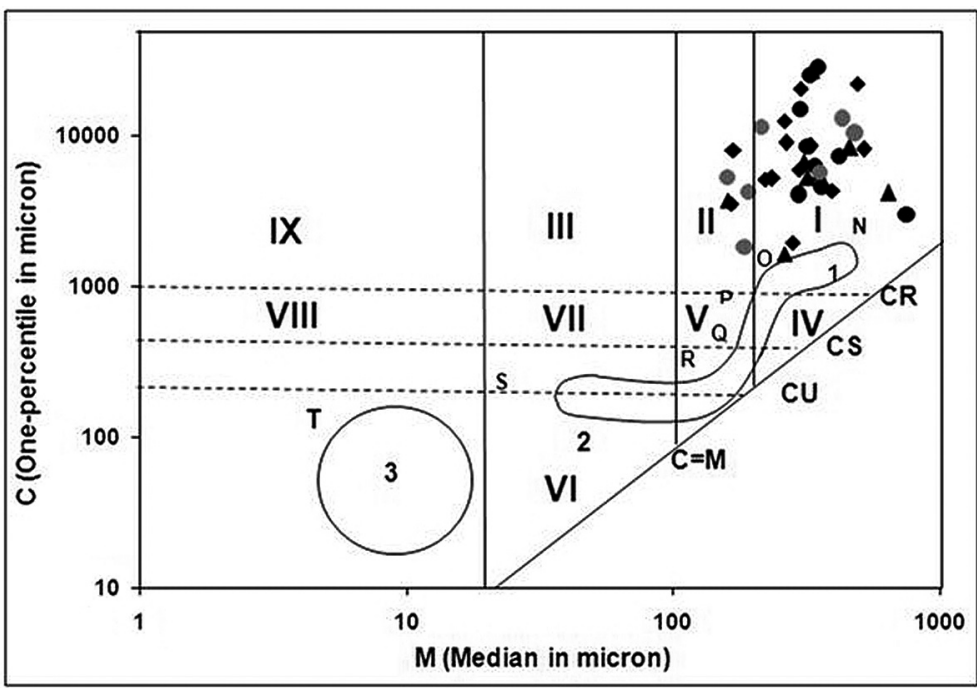

Fig. 6. C-M plot showing the concentration of grains in the extreme left corner representing dominance of rolled sediments. 
out any specific trend or clustering of points among the samples from the various areas, as all points are in the same (rolled sediment) sector (Fig. 6).

\subsection{Testing of group differences}

The primary data concerning the grain-size parameters and their relationships mentioned above seem to have little significance for establishing trends among the various glacigenic areas, though a general view can be obtained for the study area as a whole. Possible relationships between the various grain-size parameters of the four areas may be assumed to exist, however, because each agent (wind, meltwater, lake water, ice) plays a specific role. No clear trends or interrelationships were found on the basis of the above characteristics, however. Therefore we investigated the samples also for differences between the four area types by comparing their populations by means of $t-$ tests and F-tests.

\subsubsection{Results of the $t$-test}

The t-test is used for testing a hypothesis about a relationship between two sets of data (Davis, 1986). It is carried out by the formulae $\mathrm{t}=\left[\left(\overline{\mathrm{X}}_{1}-\overline{\mathrm{X}}_{2}\right)\right] / \mathrm{S}$,

where $\bar{X}_{1}$ and $\bar{X}_{2}$ are mean values of two sets of sample data, and $S$ is the combined deviation of the two sets of data.

In the present study, the t-test has been carried out for the mean grain size, standard deviation, skewness and kurtosis of the sediments belonging to all four glacigenic areas. For testing the significant differences between two samples, the null hypothesis $\left(\mathrm{H}_{\mathrm{o}}\right)$ was applied, assuming that the mean values of all areas are equal, i.e. $H_{0}: \mu_{i}=\mu_{i}$, where, $i$ and $j$ are the PIS, LKS, IFA and CSH, for $\mathrm{i} \# \mathrm{j} ; \mu$ is the mean value of the population.

Each calculated value was compared with the values of the other areas, thus resulting in six combinations: PIS/LKS, PIS/IFA, PIS/ CSH, LKS/IFA, LKS/CSH and IFA/CSH. All samples were taken on both equal and unequal variances and tested at $1 \%$ and $5 \%$ levels of sig-

Table 2. The t-values of six combinations of textural parameters of sediments from the four types of areas, assuming both equal and unequal variances, DF denotes degree of freedom.

\begin{tabular}{|c|c|c|c|c|c|c|c|c|c|c|c|c|c|}
\hline \multirow{3}{*}{$\begin{array}{c}\text { sample } \\
\text { no }\end{array}$} & \multirow{3}{*}{ area code } & \multirow{2}{*}{\multicolumn{2}{|c|}{ ttab }} & \multirow{3}{*}{ Df } & \multicolumn{9}{|c|}{ tcal } \\
\hline & & & & & \multicolumn{2}{|c|}{ mean } & \multicolumn{2}{|c|}{ skewness } & \multicolumn{2}{|c|}{ kurtosis } & \multicolumn{2}{|c|}{$\begin{array}{l}\text { standard } \\
\text { deviation }\end{array}$} & \multirow{2}{*}{ outcome } \\
\hline & & $(1 \%)$ & $(5 \%)$ & & $\leqq$ ఏ్స & ్ㅠㄹ & $\leqq$ ఏ్స & సี & $\leqq \stackrel{\frac{\pi}{2}}{g}$ & స్త్ర & $\leqq$ Е & స్త్ & \\
\hline 1 & PIS/LKS & 2.602 & 1.753 & 15 & 0.3762 & 0.3568 & 0.7093 & 0.7009 & 01404 & 0.1252 & 0.1320 & 0.1085 & non-significant \\
\hline 2 & PIS/IFA & 2.650 & 1.771 & 13 & 0.1863 & 0.1798 & 0.7477 & 0.7542 & 0.3482 & 0.3384 & 0.3426 & 0.3303 & non-significant \\
\hline 3 & PIS/CSH & 2.539 & 1.729 & 19 & 0.3954 & 0.3765 & 0.7930 & 0.7825 & 0.6544 & 0.6600 & 0.5801 & 0.5906 & non-significant \\
\hline 4 & LKS/IFA & 2.624 & 1.761 & 14 & 0.0410 & 0.0203 & 0.9603 & 0.9602 & 0.0438 & 0.0224 & 0.0542 & 0.0310 & non-significant \\
\hline 5 & LKS/CSH & 2.528 & 1.725 & 20 & 0.0266 & 0.0378 & 0.7542 & 0.7704 & 0.0296 & 0.0450 & 0.0345 & 0.0496 & non-significant \\
\hline 6 & IFA/CSH & 2.552 & 1.734 & 18 & 0.4300 & 0.3810 & 0.8017 & 0.8231 & 0.5272 & 0.5028 & 0.5756 & 0.5515 & non-significant \\
\hline
\end{tabular}

Table 3. One-way ANOVA for the textural parameters of the sediments from the various types of areas. Values between brackets show the degrees of freedom $\left(\mathrm{v}_{1}, \mathrm{v}_{2}\right): \mathrm{v}_{1}$ for the samples and $\mathrm{v}_{2}$ for the error factor.

\begin{tabular}{|c|c|c|c|c|}
\hline \multirow{2}{*}{ grain-size parameters } & \multirow{2}{*}{ Fcal } & \multicolumn{2}{|c|}{ Ftab } & \multirow{2}{*}{ outcome } \\
\hline & & $1 \%$ & $5 \%$ & \\
\hline mean & 2.4740 & 4.41 & $2.88(3,33)$ & non-significant \\
\hline standard deviation & 2.0592 & 4.41 & $2.88(3,33)$ & non-significant \\
\hline skewness & 0.0662 & 4.41 & $2.88(3,33)$ & non-significant \\
\hline kurtosis & 2.1907 & 4.41 & $2.88(3,33)$ & non-significant \\
\hline
\end{tabular}


nificance. Table 2 shows the calculated values and their comparisons with the standard table values, indicating that there is no significant difference between the means of the six combinations of the four glacigenic areas. Similarly, the values for the standard deviation, skewness and kurtosis showed to be not significant.

\subsubsection{Results of the F-test}

After getting the initial results from the $t$ test between the grain-size parameters of the four areas, which indicated non-significant relationships, the F-test was applied for oneway and two-way variances of the samples, for a number of samples from the four areas; this concerned the $\Phi$-values of the $95,84,75,50,25$, 16,5 and 1 percentiles, as well as the grain-size parameters (mean, standard deviation, skewness and kurtosis).

This test was carried out to find out whether the two population variances are equal, and what are the differences in significance between the means of several samples (cf. Dean \& Voss 1999; Walpole et al., 2004). The calca- lations were made using the formula $\mathrm{F}=\mathrm{s}_{1}^{2} /$ $\mathrm{s}_{2}{ }^{2}$, where $\mathrm{s}_{1}{ }^{2}$ and $\mathrm{s}_{2}{ }^{2}$ are the mean sum of the square of the first and second factor, respectively. These factors are the different $\Phi$-values and various textural parameters of the samples from the four areas.

(1) A one-way ANOVA was applied to the mean, standard deviation, skewness and kurtosis of the sediments from the four areas. Table 3 shows the calculated values and table values at the 1 and 5 percentile levels. All results are non-significant.

(2) A two-way ANOVA was applied to the four glacigenic areas to test the possible significance of a relationship between the various $\Phi$-values and the grain-size parameters of the samples.

First the combinations of samples and $\Phi$-values for all four areas were considered. After comparing the calculated values of the Fstatistics with the values in the table, at both the $1 \%$ and $5 \%$ levels of significance, it was found that the various samples are non-significant for all the four areas, whereas the $\Phi$-values are

Table 4. Two-way ANOVA between samples and $\Phi$-values. Values between brackets show the degrees of freedom $\left(\mathrm{v}_{1^{\prime}}\right.$ $\left.v_{2}\right): v_{1}$ for the samples and $v_{2}$ for the error factor.

\begin{tabular}{|c|c|c|c|c|c|c|c|c|c|}
\hline \multirow{2}{*}{ sample no } & \multirow{2}{*}{$\begin{array}{l}\text { area } \\
\text { code }\end{array}$} & \multicolumn{4}{|c|}{ between samples } & \multicolumn{4}{|c|}{ between $\mathrm{N}$-values } \\
\hline & & Fcal & Ftab (1\%) & Ftab (5\%) & outcome & Fcal & Ftab (1\%) & Ftab (5\%) & outcome \\
\hline 1 & PIS & 0.520448 & 3.03 & $\begin{array}{c}2.21 \\
(7,49)\end{array}$ & $\begin{array}{c}\text { non- } \\
\text { significant }\end{array}$ & 47.30561 & 3.03 & $\begin{array}{c}2.21 \\
(7,49)\end{array}$ & significant \\
\hline 2 & LKS & 0.735441 & 2.90 & $\begin{array}{c}2.14 \\
(8,56)\end{array}$ & $\begin{array}{c}\text { non- } \\
\text { significant }\end{array}$ & 179.0837 & 2.90 & $\begin{array}{c}2.21 \\
(7,56)\end{array}$ & significant \\
\hline 3 & IFA & 0.424076 & 3.51 & $\begin{array}{c}2.30 \\
(6,42)\end{array}$ & $\begin{array}{c}\text { non- } \\
\text { significant }\end{array}$ & 27.57568 & 3.51 & $\begin{array}{c}2.21 \\
(7,42)\end{array}$ & significant \\
\hline 4 & $\mathrm{CSH}$ & 1.09894 & 2.42 & $\begin{array}{c}1.88 \\
(12,84)\end{array}$ & $\begin{array}{c}\text { non- } \\
\text { significant }\end{array}$ & 34.69472 & 2.42 & $\begin{array}{c}2.13 \\
(7,84)\end{array}$ & significant \\
\hline
\end{tabular}

Table 5. Two-way ANOVA for the samples of the various types of areas and for their textural parameters. The values between brackets show the degrees of freedom $\left(\mathrm{v}_{1}, \mathrm{v}_{2}\right): \mathrm{v}_{1}$ for the samples and $\mathrm{v}_{2}$ for the error factor.

\begin{tabular}{|c|c|c|c|c|c|c|c|c|c|}
\hline \multirow{3}{*}{ area code } & \multicolumn{4}{|c|}{ between samples } & \multicolumn{5}{|c|}{ between grain-size parameters } \\
\hline & \multirow{2}{*}{ Fcal } & \multicolumn{2}{|c|}{ Ftab } & \multirow{2}{*}{$\begin{array}{l}\text { outcome at } \\
\text { both levels }\end{array}$} & \multirow{2}{*}{ Fcal } & \multicolumn{2}{|c|}{ Ftab } & \multirow{2}{*}{$\begin{array}{c}\text { outcome } \\
1 \%\end{array}$} & \multirow{2}{*}{$\begin{array}{c}\text { outcome } \\
5 \%\end{array}$} \\
\hline & & $1 \%$ & $5 \%$ & & & $1 \%$ & $5 \%$ & & \\
\hline PIS & 0.868 & 3.84 & $\begin{array}{c}2.58 \\
(7,18)\end{array}$ & $\begin{array}{l}\text { non-signif- } \\
\text { icant }\end{array}$ & 22.353 & 5.09 & $\begin{array}{c}3.16 \\
(3,18)\end{array}$ & significant & significant \\
\hline LKS & 1.877 & 3.36 & $\begin{array}{c}2.36 \\
(8,24)\end{array}$ & $\begin{array}{l}\text { non-signif- } \\
\text { icant }\end{array}$ & 13.796 & 4.72 & $\begin{array}{c}3.01 \\
(3,24)\end{array}$ & significant & significant \\
\hline IFA & 0.239 & 4.01 & $\begin{array}{c}2.66 \\
(6,18)\end{array}$ & $\begin{array}{l}\text { non-signif- } \\
\text { icant }\end{array}$ & 4.8906 & 5.09 & $\begin{array}{c}3.16 \\
(3,18)\end{array}$ & $\begin{array}{l}\text { non-signif- } \\
\text { icant }\end{array}$ & significant \\
\hline $\mathrm{CSH}$ & 0.75 & 2.75 & $\begin{array}{c}2.88 \\
(12,36)\end{array}$ & $\begin{array}{l}\text { non-signif- } \\
\text { icant }\end{array}$ & 1.4728 & 4.41 & $\begin{array}{l}2.045 \\
(3,36)\end{array}$ & $\begin{array}{l}\text { non-signif- } \\
\text { icant }\end{array}$ & $\begin{array}{l}\text { non-signif- } \\
\text { icant }\end{array}$ \\
\hline
\end{tabular}


significant, because $\Phi$-values are based on the diameter of the particles (Table 4).

Then the combinations of samples and grain-size parameters of all four areas were tested. It was found here, too, that the various samples are non-significant for all areas. The grain-size parameters were found to be significant for two areas, namely the PIS and LKS, whereas they were found to be non-significant for the CSH; for the IFA it is significant at the $5 \%$ level but non-significant at the $1 \%$ level of significance (Table 5).

\section{Discussion and conclusions}

Thirty-seven sand/silt/clay samples were collected from four different area types of the Schirmacher Oasis, viz. from the polar ice sheet, lakes, the ice-free area and the coastalshelf area. Their grain size and the grain-size parameters were analysed and subjected to tests to recognise group differences. The most important conclusions are summarised here;

(1) The average mean grain-size values indicate that the entire area is dominated by medium sand, though all four area types are built of a considerable mixture of medium to fine grains. However, the average mean values decrease in size with a trend of PIS $=$ LKS > $\mathrm{CSH}>\mathrm{IFA}$. The sorting is poor, though also here a trend exists: IFA > CSH > PIS > LKS. The lake sediments come close to being very poorly sorted. Some samples show a moderate sorting i.e., $0.81 \Phi(\mathrm{S}-3), 0.84 \Phi(\mathrm{S}-8)$ and $0.89 \Phi(\mathrm{I}-5)$ as a result of a continuous local meltwater stream that removes fine grains from the sediment.

(2) The skewness indicates a predominance of coarse or fine sediment admixtures, which is also shown by the standard deviation: IFA $>\mathrm{CSH}>$ PIS > LKS. Near-symmetrical to fineskewed sediments dominate the entire area, however, indicating a comparatively large admixture of medium to fine particles. Similarly, the kurtosis shows that coarse to fine sediments have a relatively better sorting in the polar ice, whereas medium and fine sediments are better sorted in the lake sediments. The IFA and CSH sediments show a better sorting with respect to the medium grain size.
(3) Various scatter plots of the mean vs. the standard deviation, of the mean vs. the skewness and of the mean vs. the kurtosis lack any clear pattern. In general, the poorly to very poorly sorted sediments have a faint tendency to increase in skewness with decreasing grain size; the medium-sized sediments are dominantly platykurtic to mesokurtic. The median vs. the standard deviation, the standard deviation vs. the skewness, and the skewness vs. the kurtosis plots do not show any clear trend either.

(4) Though the oasis contains four clearly different types of area, viz. PIS, IFA, LKS, and $\mathrm{CSH}$, it appears difficult to distinguish them on the basis of grain-size parameters of the sediments. Most of the sediments are poorly to very poorly sorted. Deviations occur in a few samples, due to local meltwater activity or a unidirectional wind; both agents occasionally contribute to a somewhat better sorting.

(5) The null hypothesis concerning the means of two populations (i.e., the t-test) and the means of more than two populations (i.e., the F-test) have been applied for samples, $\Phi$-values and grain-size parameters of the various glacigenic areas. It indicates that relationships between the samples are non-significant, whereas the $\Phi$-values are significant. The textural parameters for the PIS, LKS and IFA are significant, while those for the $\mathrm{CSH}$ are nonsignificant.

The lack of any definite trend in the grainsize parameters of the various glacigenic areas is understandable if the geological agents responsible for the accumulation of the sediments (i.e., wind, meltwater, glacial outlets, etc.) are taken into account. Table 6 shows the major agents and processes responsible for the accumulation of the sediments in the various areas. The area as a whole is characterised by low- to high-speed winds which act as a major erosional agent, but in lee-side areas also as a depositional agent. It also reworks the sediments of the whole area during the four months of the summer, when the surface of the oasis is maximally exposed. The strong winds act as a powerful agent that mixes sediments of all glacigenic area types in a haphazard way. The summer is also the time of maximum melt- 
Table 6. Range, average and most important textural parameters of the sediments from the various types of areas. Physical agents and the processes responsible for sediment accumulation are also summarised. Figures between brackets show the number of samples belonging to a particular category. Note that the average mean value of the sediments from the polar ice sheet is less than that of those from the shelf ice.

\begin{tabular}{|c|c|c|c|c|c|c|}
\hline \multirow{2}{*}{$\begin{array}{l}\text { area } \\
\text { code }\end{array}$} & \multicolumn{4}{|c|}{$\begin{array}{l}\text { range, average and dominant textural parameters of the sedi- } \\
\text { ments }\end{array}$} & \multirow{2}{*}{$\begin{array}{l}\text { physical agents } \\
\text { responsible } \\
\text { for sediment } \\
\text { deposition (in } \\
\text { decreasing } \\
\text { order) }\end{array}$} & \multirow{2}{*}{$\begin{array}{l}\text { depositional } \\
\text { process } \\
\text { (in decreasing } \\
\text { order) }\end{array}$} \\
\hline & mean $[\mathbf{N}]$ & $\begin{array}{c}\text { standard devia- } \\
\text { tion }\end{array}$ & skewness & kurtosis & & \\
\hline 8 samples & $\begin{array}{c}\text { range: } 0.93-2.27 \\
\text { average: } 1.33 \\
\text { medium sand } \\
\qquad(4) \\
\text { coarse sand (3) } \\
\text { fine sand }(1)\end{array}$ & $\begin{array}{c}\text { range: } 1.00-2.08 \\
\text { average: } 1.70 \\
\text { poor sorting }(6) \\
\text { medium sorting } \\
\quad(1) \\
\text { very poor sort- } \\
\text { ing }(1)\end{array}$ & $\begin{array}{c}\text { range: } \\
-0.14-+0.3 \\
\text { fine skewed }(4) \\
\text { very fine } \\
\text { skewed }(2) \\
\text { near-symmetri- } \\
\text { cal }(1) \\
\text { coarse skewed } \\
(1)\end{array}$ & $\begin{array}{c}\text { range: } 0.62-1.43 \\
\text { average } 1.01 \\
\text { leptokurtic (3) } \\
\text { mesokurtic (2) } \\
\text { platykurtic (2) } \\
\text { very platykurtic } \\
\quad(1)\end{array}$ & ice and wind & $\begin{array}{l}\text { settling from } \\
\text { suspension }\end{array}$ \\
\hline 9 samples & $\begin{array}{c}\text { range: } 0.47-1.64 \\
\text { average: } 1.33 \\
\text { medium sand } \\
(7) \\
\text { coarse sand (3) }\end{array}$ & $\begin{array}{c}\text { range: } 1.50-2.22 \\
\text { average: } 1.19 \\
\text { poor sorting (5) } \\
\text { very poor sort- } \\
\text { ing }(4)\end{array}$ & $\begin{array}{c}\text { range: } \\
-0.006-+0.3 \\
\text { fine skewed (5) } \\
\text { very fine } \\
\text { skewed (1) } \\
\text { near-symmetri- } \\
\text { cal (3) }\end{array}$ & $\begin{array}{c}\text { range: } 0.66 \\
-1.29 \\
\text { average } 0.81 \\
\text { leptokurtic (3) } \\
\text { mesokurtic (2) } \\
\text { platykurtic (6) } \\
\text { very platykurtic } \\
(1)\end{array}$ & $\begin{array}{l}\text { lake water; } \\
\text { gravitation } \\
\text { supplying } \\
\text { sediments from } \\
\text { surrounding } \\
\text { higher areas; } \\
\text { meltwater }\end{array}$ & $\begin{array}{c}\text { lacustrine sedi- } \\
\text { mentation; } \\
\text { washing from } \\
\text { nearby elevated } \\
\text { areas; } \\
\text { meltwater } \\
\text { deposition }\end{array}$ \\
\hline $\begin{array}{c}\text { IFA } \\
7 \text { samples }\end{array}$ & $\begin{array}{c}\text { range: } 0.89-2.3 \\
\text { average: } 1.74 \\
\text { fine sand }(4) \\
\text { coarse sand }(2)\end{array}$ & $\begin{array}{c}\text { range: } 0.89-2.25 \\
\text { average: } 1.49 \\
\text { poor sorting (5) } \\
\text { very poor sort- } \\
\text { ing (1) } \\
\text { moderate sort- } \\
\text { ing }(1)\end{array}$ & $\begin{array}{c}\text { range: } \\
-0.01-+0.3 \\
\text { fine skewed (3) } \\
\text { very fine } \\
\text { skewed (1) } \\
\text { near-symmetri- } \\
\text { cal (3) }\end{array}$ & $\begin{array}{c}\text { range: } 0.70-1.70 \\
\text { average } 1.18 \\
\text { leptokurtic (2) } \\
\text { mesokurtic (1) } \\
\text { very leptokurtic } \\
(2) \\
\text { platykurtic (2) }\end{array}$ & $\begin{array}{l}\text { wind; } \\
\text { meltwater }\end{array}$ & $\begin{array}{c}\text { meltwater } \\
\text { deposition; } \\
\text { aeolian deposi- } \\
\text { tion }\end{array}$ \\
\hline 13 samples & $\begin{array}{c}\text { range: } 0.91-2.42 \\
\text { average: } 1.52 \\
\text { medium sand } \\
(10) \\
\text { coarse sand }(2) \\
\text { fine sand }(1)\end{array}$ & $\begin{array}{c}\text { range: } 0.81-2.08 \\
\text { average: } 1.61 \\
\text { poor sorting } \\
(10) \\
\text { very poor sort- } \\
\text { ing (1) } \\
\text { moderate sort- } \\
\text { ing }(2)\end{array}$ & $\begin{array}{c}\text { range: } \\
-0.03-+0.3 \\
\text { fine skewed (4) } \\
\text { very fine } \\
\text { skewed (3) } \\
\text { near-symmetri- } \\
\text { cal (5) } \\
\text { coarse skewed } \\
(1)\end{array}$ & $\begin{array}{c}\text { range: } 0.69 \\
-2.02 \\
\text { average: } 1.70 \\
\text { leptokurtic (3) } \\
\text { mesokurtic (4) } \\
\text { platykurtic (5) } \\
\text { very leptokurtic } \\
\text { (1) }\end{array}$ & $\begin{array}{l}\text { ocean water; } \\
\text { wind; } \\
\text { meltwater }\end{array}$ & $\begin{array}{l}\text { coastal-shelf } \\
\text { deposition; } \\
\text { meltwater } \\
\text { deposition }\end{array}$ \\
\hline
\end{tabular}

ing of ice, allowing the embedded sediments to be transported over a distance that is related to their size. The larger particles remain at the same place, with little or no movement, whereas the finer fractions may stay at the same place or move along with meltwater for some distance. The meltwater streams supply sediment to the entire area, but without any observable trend.

During the cold months, the rocky surface of the oasis gets covered by ice whereas the perennial frozen areas, i.e. the polar ice sheet and the coastal shelf, experience a thicker ice layer than during the summer season. Moreover, the winds are stronger, and cover them with a thick snow cover and with sediment. These sediments accumulate without a clear spatial pattern. The wind regime and meltwater are significant factors in polar regions for erosion and transport, due to the persistent high wind speed and the high density of cold water. These factors also affect the grain size of the sediments (Atkins \& Dunbar, 2009). Meltwater is also an important factor in the transport and accumulation of the sediments in the study area, but meltwater is present for a short time 
only, viz. from October to February. Meltwater plays a significant role in winnowing, sorting of the sediments as well as washing away of the fine grained, lighter and platy minerals, finally affecting the overall textural and geochemical set-up (Gore et al., 2003). The coastal-shelf sediments of the study area consist on average of grains with a medium sand size; they show poor sorting and their fine to near-symmetrical skewness is comparable with that of the gravelly muds, muddy sands and sands with up to $25 \%$ of gravel that extend to the marine shelf areas of the Weddell Sea, where it is a result of the combined activity of tidal and coastal currents and ice-shelf water flows (Diekman \& Khun, 1999).

The poor sorting of the sediments from the lakes and the ice-free area is also primarily the result of the activity of wind and meltwater. The source of the sediments consists mainly of the highly metamorphosed host rocks and intrusions, as shown by the heavy minerals: zircon, tourmaline, rutile, garnet, hornblende, zoisite, lawsonite, chlorite, spinel, topaz and opaque minerals (Srivastava et al., 2010). These minerals are set free from the host rock by glacial erosion and frost action. Chemical weathering and alteration also play a role, as indicated by the clay minerals: chlorite, illite, kaolnite and smectite (Srivastava et al., 2011). The sediments released by the net effect of all processes involved exhibit a wide size range, influenced further by wind and meltwater. Since the icefree area is very small and the sediments are highly reworked by wind and meltwater in a limited region, the grains lose to some extent - while the sediments remain unsorted - their initially angular shape: the pebble-sized clasts are mainly subangular to subrounded. In the case of low lying lakes, additional influx of poorly sorted sediments from local sources, downslope from the adjoining hills or elevated areas, is a common feature (Verkulich \& Melles, 1992) which reduces the sorting as well as affects the other grain-size parameters.

\section{Acknowledgements}

AKS is indebted to NCAOR, Goa, for providing the opportunity to work in Antarctica as a member of the Summer Team, $21^{\text {st }}$ Indian Antarctica Expedition, organised by the Government of India, DOD, New Delhi. The help from, and cooperation with Sri R.P.Lal (Team Leader) during theexpedition is gratefully acknowledged. Financial support in the form of a major research project, No. 24/287/06EMR-II, to AKS is also gratefully acknowledged.

\section{References}

Asthana, R. \& Chaturvedi, A., 1998. The grain size behavior and morphoscopy of supraglacial sediments, south of Schirmacher Oasis, E. Antarctica. Journal of the Geological Society of India 52, 557-568.

Atkins, C.B. \& Dunbar, G.B., 2009. Aeolian sediment flux from sea ice into Southern McMurdo Sound, Antarctica. Global and Planetary Change 9, 133-141.

Bera, S.K., 2004. Late Holocene palaeo-winds and climatic changes in eastern Antarctica as indicated by longdistance transported pollen-spores and local microbiota in polar lake core sediments. Current Science 86, 1485-1488.

Chaturvedi, A., Singh, A. \& Venkateshwarlu, S., 1999. Annual cycle of permafrost migration in Schirmacher Oasis. Scientific Report, $15^{\text {th }}$ Indian Scientific Expedition to Antarctica, Department of Ocean Development, Government of India, Technical Publication 13, 265-279.

Davis, J.C., 1986. Statistics and data analysis in geology $\left(2^{\text {nd }}\right.$ ed.). John Wiley and Sons, New York, 646 pp.

Dean, A.M. \& Voss, D., 1999. Design and analysis of experiments. Springer-Verlag, Heidelberg, 740 pp.

Diekmann, B. \& Kuhn, G., 1999. Provenance and dispersal of glacial-marine surface sediments in the Weddell Sea and adjoining areas, Antarctica: ice-rafting versus current transport. Marine Geology 158, 209-231.

Folk, R.L., 1980. Petrology of sedimentary rocks. Hemphill, Austin, 159 pp.

Folk, R.L. \& Ward, W., 1957. Brazos river bar: a study in the significance of grain size parameters. Journal of Sedimentary Petrology 27, 3-26.

Friedman, G.M., 1961. Distinction between dune, beach and river sands from their textural characteristics. Journal of Sedimentary Petrology 31, 514-529.

Friedman, G.M., 1967. Dynamic processes and statistical parameters compared for size frequency distribution of beach and river sands. Journal of Sedimentary Petrology 37, 327-354.

Gajananda, K., Dutta, H.N. \& Lagun, V.E., 2007. An episode of coastal advection fog over East Antarctica. Current Science 93, 654-659.

Hoch, M., 1999. Geochemistry and petrology of ultramafic lamprophyres from Schirmacher Oasis, East Antarctica. Mineralogy \& Petrology 65, 51-67.

Hoch, M. \& Tobschall, H.J., 1998. Minettes from Schirmacher Oasis, East Antarctica - indicators of an enriched mantle source. Antarctic Science 10, 476-486.

Hoch, M., Rehkamper, M. \& Tobschall, H.J., 2001. Sr, Nd, $\mathrm{Pb}$ and $\mathrm{O}$ isotopes of minettes from Schirmacher Oa- 
sis, East Antarctica: a case of mantle metasomatism involving subducted continental material. Journal of Petrology 42, 1387-1400.

Ingram, R.L., 1971. Sieve analysis. [In:] Carver R.E. (Ed.): Procedures in sedimentary petrology. Wilson Interscience, 49-68.

Karczewski, A., Rachlewicz, G. \& Szczucinski, W., 2003. Sediment texture in contemporary glacial environment - examples from Hansbreen, southern Spitsbergen. Geologos 6, 111-131.

Lal, M., 1986. Sedimentology of the glacial sands and lake terraces sediments from Schirmacher Oasis and sea bed sediment of Princess Astrid Coast, Queen Maud Land, Antarctica. Scientific Report, $3^{\text {rd }}$ Indian Scientific Expedition to Antarctica, Department of Ocean Development, Government of India, Technical Publication 3, 219-223.

Lal, R.P. \& Manchurkar, P., 2007. Study of meteorological parameters and ozone hole phenomena at Schirmacher Oasis, Antarctica during $21^{\text {st }}$ Indian expedition 2002-2003. Scientific Report, $21^{\text {st }}$ Indian Scientific Expedition to Antarctica, Department of Ocean Development, Government of India, Technical Publication 19, 73-93.

Lindholmn, R.C., 1987. A practical approach to sedimentology. Allen \& Unwin, 270 pp.

Miola, R.J. \& Weiser, D., 1968. Textural parameters: an evaluation. Journal of Sedimentary Petrology 38, 45-53.

Mycielska-Dowgiałło, E. \& Ludwikowska-Kędzia, M., 2011. Alternative interpretations of grain-size data from Quaternary deposits. Geologos 17, 189-203.

Parthasarathy, G., Sharma, S.R., Ravindran, T.R., Arora, A.K. \& Hussain, S.M., 2003. Structural and thermal studies of graphite from East Antarctica. Journal of the Geological Society of India 61, 335-343.

Passega, R., 1957. Texture as characteristics of clastic deposition. American Association of Petroleum Geologists Bulletin 41, 1952-1984.

Passega, R., 1964. Grain size representation by C-M pattern as a geological tool. Journal of Sedimentary Petro$\log y 34,830-847$.

Passega, R. \& Byramjee, R., 1969. Grain size image of clastic deposits. Sedimentology 13, 180-190.

Phartiyal, B., Sharma, A. \& Bera, S.K., 2011. Glacial lakes and geomorphological evolution of Schirmacher Oasis, East Antarctica during Quaternary. Quaternary International 23, 128-136.

Ravindra, R., 2001. Geomorphology of Schirmacher Oasis, East Antarctica. Geological Survey of India, Special Publication 53, 379-390.
Sengupta, S., 1986. Geology of Schirmacher range (Dakshin Gangotri), East Antarctica. Scientific Report, $3^{\text {rd }}$ Indian Scientific Expedition to Antarctica, Department of Ocean Development, Government of India, Technical Publication 3, 187-217.

Sharma, C., Chauhan, M.S. \& Sinha, R., 2007. Studies on Holocene climatic changes from Priyadarshini Lake sediments, Schirmacher Oasis, East Antarctica: the palynological evidence. Journal of the Geological Society of India 69, 92-96.

Singh, R.K., 1986. Geology of Dakshin Gangotri Hill Range, Antarctica. Scientific Report, $3^{\text {rd }}$ Indian Scientific Expedition to Antarctica, Department of Ocean Development, Government of India, Technical Publication 3, 181-186.

Srivastava, A.K. \& Khare, N., 2009. Granulometric analysis of glacial sediments, Schirmacher Oasis, East Antarctica. Journal of the Geological Society of India 73, 609-620.

Srivastava, A.K., Khare, N. \& Ingle, P.S. 2010. Textural characteristics, distribution pattern and provenance of heavy minerals in glacial sediments of Schirmacher Oasis, East Antarctica. Journal of the Geological Society of India 75, 393-402.

Srivastava, A.K., Khare, N. \& Ingle, P.S., 2011. Characterization of clay minerals in the sediments of Schirmacher Oasis, East Antarctica: their origin and climatological implications. Current Science 100, 363-372.

Sundararajan, N. \& Rao, M., 2005. A note on the petrophysical properties and geological interpretation in Schirmacher Oasis, East Antarctica. Journal of the Geological Society of India 65, 497-503.

Verkulich, S. \& Melles, M., 1990. Composition and paleoenvironmental implications of sediments in a fresh water lake and in marine basins of Bunger Hills, East Antarctica. Polarforschung 60, 169-180.

Visher, G.S., 1969. Grain size distributions and depositional processes. Journal of Sedimentary Petrology 39, 1074-1106.

Walpole, R.E., Myers, R.H., Myers, S.L. \& Ye, K., 2004. Probability $\mathcal{E}$ statistics for engineers $\mathcal{E}$ scientists. Prentice Hall, 730 pp. 